\title{
THEORETICAL APPROACHES TO
} UNDERSTANDING THE NATURE OF THE CASH FLOWS OF COMPANIES

\section{Galyna Drebit}

Kyiv National Economical University by V. Hetman, Finance and Economic faculty, Department of corporate finance and controlling, Kyiv, Ukraine

CMESTE

JEL Category: C51, G02

\begin{abstract}
The article deals with theoretical approaches to understanding the nature of the cash flows of companies. The question of determining the economic nature of the cash flows is extremely important both in theoretical and practical aspects, as formed approaches to the interpretation of the essence of the cash flows in the future define the fundamentals of their planning and control. The article is presented in three parts. The first part deals with the static approach to understanding the nature of the cash flows of the company in which the cash flow is interpreted from the perspective of its impact on the balance of funds in the accounts of the company and is defined as the net movement of cash for the period. The basic categories that characterize the cash flow within the static approach are: "cash balance at any given time", "net movement of cash" and "net cash flow". The second part of the article deals with the nature of the cash flows on a dynamic level. At this level, the cash flow represents the movement of cash in two ways: in the form of a plan of future cash flows of the company in time or report about their movement in prior periods. Confidence approach to the determination of the cash flows is presented in the third part of the work. The author believes this approach is the most reasonable. Using it the author in the conclusions offers to determine the cash flow as the directed movement of cash that is expressed in its receipt, distribution, and disposal from operating, investing and financing activities. The result of the movement of cash is a balance of cash and cash equivalents, which serves as a static determinant of the cash flows.
\end{abstract}

Keywords: cash flow, cash, net cash flow, the net movement of cash, revenues, spending of cash, operating, financing, investing activity.

\section{INTRODUCTION}

The question of determining the economic nature of the cash flows is extremely important both in the

Address of the author:

Galina Drebit

拝=" galyna-drebit@i.ua theoretical and practical aspects, as formed approaches to the interpretation of the essence of the cash flows in the future define the fundamentals of their planning and control.

In the foreign and domestic literature on corporate finance, theoretical and practical issues of economic nature of the cash flows of companies 
have been the subject of many research scientists and practitioners.

In the foreign and domestic literature on corporate finance, theoretical and practical issues of economic nature of the cash flows of companies have been the subject of many research scientists and practitioners.

They made a significant contribution to the development of theoretical and methodological foundations to determine the economic nature of the cash flows, of their planning and control. However, as it is evidenced by the financial theory and practice of today's there is no unified approach to determining the economic essence of the definition "the cash flow of the company" in Ukrainian and foreign science, as scientists and practitioners still continue to debate about understanding the economic nature of this category. In this regard, it is actual to develop the relevant paradigm of understanding the nature of the cash flows of the company that would include all their properties integrated.

Discovery of the economic nature of the cash flows of the company is proposed to start from the disclosure of the essence of the cash flow concept which originated in the 50-60s of the twentieth century. This concept involves forming an idea of the company as a totality of cash inflows and outflows alternating. The basis of the concept is a logical assumption that some cash flow may be associated with any financial transaction, that means a set of distributed in time payments (outflows) and receipts (inflows) arising from management decisions within the operating, investing and financing activity.

As note Fabotsi \& Drake (2010) there is no specific definition of the cash flow. Probably the reason for so much confusion about the definition of the cash flow is because it refers both to the cash inflows and outflows and to the difference between them that is a net cash flow.

Purely on the semantic level, the cash flow is a quantified expression of money that the entity has at a particular time, for the investor the cash flow is an expected future profits on investments, from the position of managers the cash flow is a plan for the future movement of cash and so on. In each case, the dynamics of movement of the company's cash is a continuous process and creates the cash flow. However, this approach to understanding the nature of the cash flows is too fragmented and does not display all aspects of this phenomenon.

The study of scientific and practical literature in corporate finance showed many meanings of the definition "the cash flow of the company." Multilevel understanding of the nature of the cash flows is due to the fact that since they form the basis of the cost of corporate economic relations, then they have the relationship with all economic processes of any enterprise. In addition, they affect significantly the final results of economic activities of companies, determine the level of their solvency and financial balance.

Based on the study of scientific and practical literature on corporate finance three approaches to understanding the nature of the cash flows of the company can be distinguished: static, dynamic and aggregated. Each of these approaches discloses the nature of the cash flows in terms of taking into account the specific characteristics possessed by the cash flows of the company.

\section{STATIC APPROACH TO UNDERSTANDING THE ESSENCE OF THE CASH FLOWS OF THE COMPANY}

Representatives of static approach interpret the cash flow from the perspective of its impact on the balance of funds in the accounts of the company and define it as a net cash flow for the period. In particular, in English online investment encyclopedia "Investopedia" (2016) the cash flow of the company is identified with a net cash flow and is regarded as the net amount of money and cash equivalents entering the company and getting out of it. Accordingly, the positive cash flow shows that the liquid assets of the company are increasing, allowing to settle debts, reinvest in the business, return money to shareholders, pay expenses and provide protection against future financial problems. The negative cash flow shows that the liquid assets of the company are reduced. In this definition, the cash flow is completely identified with the net cash flow of the company but that is not correct because the definition of "the cash flow" has greater meaning.

Within static approach to understanding the nature of the cash flows, there are other views. Pokrovskiy (2012, p. 9) explains the cash flow as the result of economic activity reflected in the 
receipt, distribution, and use of funds and depends on multivariate internal and external environment of the entity. But as we see from the given definition the cash flow in this interpretation may be associated with the profit of the company that is also a result of the economic activity of the company.

As Tennet (2014, pp. 11-12) notes profit and cash are two big differences, as income and expenses, on the basis of which income is recognized, are determined at the time of delivery of goods or services, while revenues or cash payments are determined at the time of their transfer. The time delay between the moment of recognition of events for the purposes of profit determination and availability of funds can be significant.

According to the English-language online encyclopedia "Investopedia" (2016), a net cash flow differs from the net profit which includes accounts receivable and other components on which payments were actually received. The cash flow is used for assessing the quality of revenue, shows how it is liquid and can show how much solvent it remains.

In the context of determining the difference between the cash flow and profit of the company the opinion of Brigham \& Erhardt (2009, pp. 7374 ) is also plausible. They note that the cash flow of the company is usually different from its profit which is reflected in the balance sheet because some types of income and expenses reported in the financial results do not result in actual cash payments in the reporting period. The research offers to calculate a net cash flow as net income "minus" non-cash income "plus" non-cash expenses. As the non-cash expenses (those that do not result in actual cash payments) the authors suggest amortization of tangible and intangible assets and deferred tax liabilities. At the same time, some components of the net profit can be displayed but not received in cash during the reporting period.

The definition of a net cash flow can be also met in some regulatory legal acts of Ukraine, including the Order of the State Committee of Ukraine on mineral resources "Approval of the Regulations on the procedure for the development and study of conditions on mineral raw materials for the calculation of reserves of solid minerals in the bowels" (2005). Here a net cash flow is a difference (balance) between inflows and outflows of cash from operating and investing activities during the anticipated implementation of the project.

Order of the Ministry of Economy of Ukraine "On Approval of the recommendations on the development of a company business plan" (Nakaz № 290, 2006). The cash flow from current economic (investment, financial) activity is the amount of excess (deficiency) of funds obtained from the comparison of receipts and payments of cash from operating (investment, financial) activities.

Explanation of the cash flows as cash balance can be found also in the work of Tennet $(2014$, p. 11): "The amount of money needed for the company depends on the predictability both of revenues as a result of economic activities and payments (demand) to suppliers and employees".

The cash flow according to Tennet (2014) are those cash revenues which allow the company to meet the demand for them. The alternative to this is the presence of foreign investors who are willing to fund any shortage of money. But in order to attract foreign investment company must demonstrate the ability to achieve positive cash flow that will pay interest and ultimately return the invested funds.

Thus, under a static approach, the cash flow is a free cash balance at any given time which cannot be identified with the flow (circulation, movement) because the flow means motion. The volume of the cash flow can be characterized by such indicators as the volume of funds received and the amount of money spent. As you can see from the above definitions of basic categories that characterize the cash flow within the static approach are: "the cash balance at any given time", "the net movement of cash", "the net cash flow".

According to the Professor of Financial Management $P$. Fernandez in the general understanding, the cash flow is the difference between inflows and outflows of cash, that is when the money coming into the company is bigger than those getting out of it. Fernandez (2006) notices that the company works better and "generates wealth" for shareholders when the cash flows are increasing. He notes that as a rule for the characteristics of this process four definitions of 
the cash flow are used: operating cash flow (OCF), The methods of calculating the respective types of "equity cash flow" (ECF), "free cash flow" (FCF) the cash flows are shown in Table 1.

and capital cash flow (CCF).

Table 1. The methods of calculating operating (OCF) equity (CCF), free (FCF), and capital (CCF) cash flows.

\begin{tabular}{|c|c|c|c|}
\hline & dicator & he & \\
\hline 1 & $\begin{array}{l}\text { Operating } \\
\text { cash flow } \\
\text { (OCF) }\end{array}$ & $\mathrm{OCF}=\mathrm{EBIT}+\mathrm{A}-\Delta \mathrm{WCR}-\Delta \mathrm{FA}-\Delta \mathrm{DE}$ & \multirow{5}{*}{ 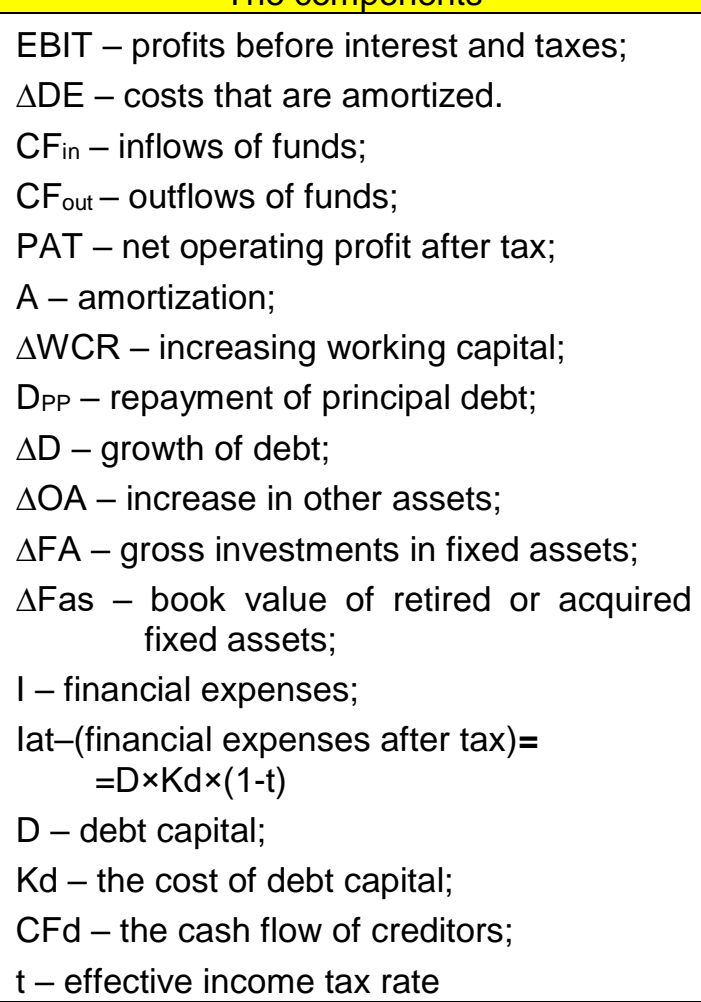 } \\
\hline 2 & $\begin{array}{l}\text { uity } \\
\text { h flow } \\
\text { F) }\end{array}$ & $\begin{array}{r}E C F=C F i n \\
E C F=P A T \\
-\Delta F\end{array}$ & \\
\hline & \multirow{2}{*}{$\begin{array}{l}\text { Free cash } \\
\text { flow } \\
\text { (FCF) }\end{array}$} & $\begin{array}{l}\text { Provided that the company has no } \\
\text { debt } \\
\mathrm{FCF}=\mathrm{ECF}\end{array}$ & \\
\hline & & $\begin{array}{l}\text { In the presence of debt } \\
F C F=P A T+A-\Delta W C R-\Delta O A-\Delta F A- \\
\Delta F a s+l a t, \\
F C F=E C F+I(1-t)-\Delta D\end{array}$ & \\
\hline & $\begin{array}{l}\text { Capital } \\
\text { cash flow } \\
\text { (CCF) }\end{array}$ & $\mathrm{CCF}=\mathrm{ECF}+\mathrm{CFd}=\mathrm{ECF}+\mathrm{I}-\Delta \mathrm{D}$ & \\
\hline
\end{tabular}

Equity cash flow (ECF) is money balances of which are available on the company after tax, after covering the necessary capital investment and the required increase in working capital (Working capital requirements, WCR), payment of financial expenses and attracting new debt and loan capital. Equity cash flow (ECF) is money available on the company for its shareholders which can be used to pay dividends or repurchase shares. The equity cash flow for the period is the difference between inflows and outflows of cash during the period. When equity cash flow is forecast for the period it must be equivalent to the projected dividends plus treasury shares in this period (Fernandez, 2006).

Free cash flow (FCF) is the cash flow by operating activities after tax without including in the calculation the level of a debt burden that is without deduction of financial expenses of the company. These are remains of cash available in the company after covering the necessary capital investment and working capital requirements (WCR), assuming there is no debt. It is quite often believed that free cash flow (FCF) represents cash generated by the company for providers of financial resources which are the shareholders and creditors, but it is not like that because the parameter that reflects the cash funds generated by the company to its shareholders and creditors is called capital cash flow (CCF).

Capital cash flow (DCF) is a cash flow that is available to creditors plus equity cash flow (ECF). Cash flow to creditors (CFd) consists of amounts of interest payments plus repayment of the principal sum of debt. 


\section{Profit before interest and taxes (EBIT)}

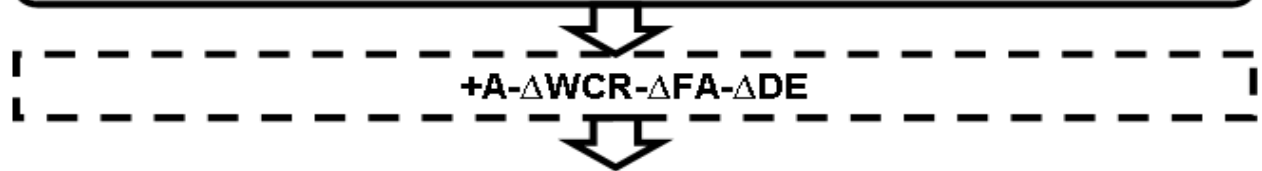

\section{Operating cash flow (OCF)}

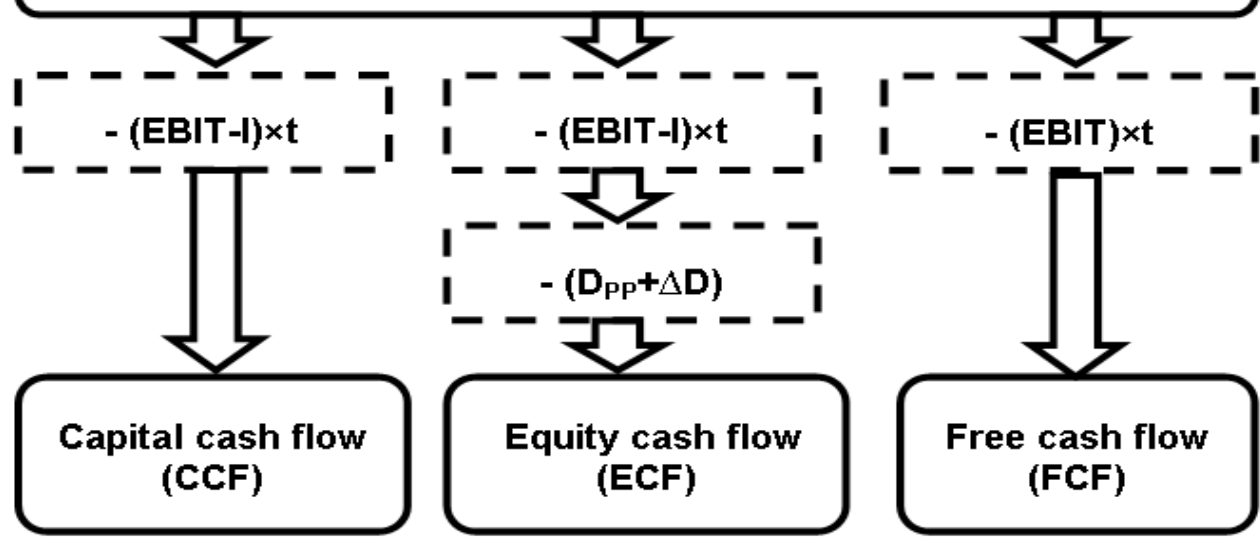

Fig.1. The relationship between different types of cash flows (Fernandez, 2006)

\section{DEFINITION OF THE ESSENCE OF THE CASH FLOWS OF THE COMPANY ON THE DYNAMIC LEVEL}

On the dynamic level, the cash flow represents the movement of cash in two ways: in the form of a plan of future movement of company's cash in time or report about their movements in prior periods. According to Kovalev (2008, p. 44), cash receipts, revenues, expenses, profits and other payments may occur as a part of the cash flow. In most cases, it is about the expected cash flows. For these flows formalized methods and criteria to make informed financial decisions have been developed. According to Prof. Xaxonova N. M. (2014) the cash flow is a targeted movement of cash and cash equivalents measured in terms of money per unit of time.

Within the dynamic approach, the category of the cash flow is often identified with the "payments flow" that is why it is necessary to determine the economic essence of this economic category. Differences between cash flows and payments are noted in the works of J. Brigham and M. Erhardt "Financial management", who divide all cash flows according to their uniformity into constant regular cash flows called payments and the actual cash flows when it is about irregular payments or receipts.

According to Sirotkina \& Kelchevskaya (2011, pp. 27-28), the definition "payments flow" can be interpreted in two ways. On the one hand, the flow is considered as the directed movement of material or financial resources and on the other hand as a series of payments over time that is a set of sums of money each of which refers to a certain period of time. The second definition appeared because the movement of economic resources of the company is characterized by the presence of not separate concurrent payments but some of their sequence in time. This sequence of payments which includes incoming and outgoing of cash is called the payments flow. In this case, as the authors claim, the payments flow is a financial planning tool. Elements of the flows are separate payments which may forecast both the incoming of cash and its outgoing.

It should be noted that in the scientific literature within the dynamic approach there is a number of other similar definitions of the category "the cash flow of the company" (Table 2). 
Table 2. Defining the essence of "the cash flows" within the dynamic approach

\begin{tabular}{|c|c|c|}
\hline № & Source & The essence of "the cash flows" \\
\hline 1 & $\begin{array}{l}\text { Act of CMU "General } \\
\text { principles of property } \\
\text { valuation and property } \\
\text { rights" } \\
\text { Number of IAS } 7 \\
\text { "Statement of Cash } \\
\text { Flows"; }\end{array}$ & $\begin{array}{l}\text { The cash flow is the amount of actual or projected revenue from the } \\
\text { activity (use) of the assessment subject. }\end{array}$ \\
\hline 2 & $\begin{array}{l}\text { Act of CMU №4 "Report } \\
\text { of Cash Flows" }\end{array}$ & The cash flow is a receipt and disposal of cash and cash equivalents. \\
\hline 3 & Bazilinska O.Ya. & The cash flows are inflows and outflows of cash and its equivalents. \\
\hline 4 & Blank I.O. & $\begin{array}{l}\text { The cash flow of the company is a collection of receipts and payments of } \\
\text { cash, distributed into separate intervals over the examined period of time, } \\
\text { that are generated by its economic activity, the movement of which is } \\
\text { related to the time, risk and liquidity factor. }\end{array}$ \\
\hline 5 & Butynetz F.F. & $\begin{array}{l}\text { The cash flows are receipts and payments of cash, which is one of the } \\
\text { most important independent objects of financial analysis that is conducted } \\
\text { to assess the financial stability and solvency }\end{array}$ \\
\hline 6 & Kramarenko H.A. & $\begin{array}{l}\text { The cash flow is a set of distributed in time receipts and disposals of funds } \\
\text { generated by the economic activity of the company }\end{array}$ \\
\hline 7 & $\begin{array}{l}\text { Kalambet S.V. } \\
\text { Yakymova A.M. }\end{array}$ & $\begin{array}{l}\text { The cash flow is distributed in time inflow and outflow of the company, that } \\
\text { is a movement for cash accounts of the company }\end{array}$ \\
\hline 8 & $\begin{array}{l}\text { Lihonenko L.O. } \\
\text { Sytnyk H.V. }\end{array}$ & $\begin{array}{l}\text { The cash flow is a system of distributed in time revenues and expenditures } \\
\text { of cash generated by its economic activity and accompany the movement } \\
\text { of value, having an external sign of functioning of the company }\end{array}$ \\
\hline 9 & Lykasevych I.Ya. & $\begin{array}{l}\text { The cash flow is distributed in time movement of the cash flows arising } \\
\text { from an economic activity or of certain transactions of a subject. He notes } \\
\text { that the term "the cash flow" is fundamental in financial management and } \\
\text { is an important object of financial management. }\end{array}$ \\
\hline 10 & Kramenko V.I. & $\begin{array}{l}\text { The cash flow is the collection of income and outflow of funds for a certain } \\
\text { period of time, formed in the course of economic activity }\end{array}$ \\
\hline 11 & $\begin{array}{l}\text { Kovalenko L.O. } \\
\text { Remniova L.M. }\end{array}$ & $\begin{array}{l}\text { The cash flow is a receipt and disposal of cash and cash equivalents as a } \\
\text { result of the industrial and economic activity of the company. }\end{array}$ \\
\hline 12 & Mnyh Ye. V. & $\begin{array}{l}\text { The cash flow is a set of distributed in time receipts and disbursements of } \\
\text { funds generated by its economic activities }\end{array}$ \\
\hline 13 & Savytska H.V. & $\begin{array}{l}\text { The cash flow is a continuous process of cash flow over time, which is } \\
\text { vividly compared with a system of "financial circulation" which ensures the } \\
\text { viability of the organization. }\end{array}$ \\
\hline 14 & $\begin{array}{l}\text { Starostenko H.H. } \\
\text { Mirko N.V. }\end{array}$ & $\begin{array}{l}\text { The cash flow is revenues and expenditures of funds in the } \\
\text { implementation of the economic activities of the company }\end{array}$ \\
\hline 15 & $\begin{array}{l}\text { Vynohradova E.V., } \\
\text { Lastovenko A.V., } \\
\text { Belopolskaia T.V. }\end{array}$ & $\begin{array}{l}\text { The cash flow is a receipt and expenditure of cash and cash equivalents, } \\
\text { which lead to changes in the cost structure of property of the entity in } \\
\text { composition and sources of the formation. }\end{array}$ \\
\hline
\end{tabular}


As it can be seen in Tab. 2 according to a dynamic approach to the essence of the cash flows some scientists define "the movement of cash" as determinants of the cash flow and the others define "revenue and expenditure of funds" and "the payments flow". The cash flow is not a constant at a certain date (as noted under a static approach to the cash flow) but rather a circulation of cash for a certain period. Circulation and movement reveal the essence of the category "the cash flow", the circulation and movement are the main features of this category, the cash flows are inextricably linked with them. The process of the movement of cash occurs in time and space during maintenance of all types of economic activities.

Zhezhel Yu.V. proves the following distinctive features of static and dynamic approaches to the study of cash (Table 3).

Table 3 Distinctive features of static and dynamic approaches to interpretation of the cash flows *

\begin{tabular}{|l|l|l|l|}
\hline № & $\begin{array}{l}\text { The criterion of } \\
\text { evaluation }\end{array}$ & \multicolumn{1}{|c|}{ The static approach } & \multicolumn{1}{c|}{ The dynamic approach } \\
\hline 1 & Object of study & $\begin{array}{l}\text { The static value of the reserve } \\
\text { funds of the entity }\end{array}$ & $\begin{array}{l}\text { Movement, changing of cash of the entity } \\
\text { for a certain period of time }\end{array}$ \\
\hline 2 & Time of studies & $\begin{array}{l}\text { The reporting date or a set of } \\
\text { reporting dates }\end{array}$ & A certain period of time \\
\hline 3 & $\begin{array}{l}\text { Methodological } \\
\text { basis of research }\end{array}$ & $\begin{array}{l}\text { Description of indicators of } \\
\text { cash balance readies for a } \\
\text { reporting date }\end{array}$ & $\begin{array}{l}\text { Description of the enterprise dynamics } \\
\text { considering the totality of the factors } \\
\text { influencing the movement and } \\
\text { transformation of funds }\end{array}$ \\
\hline of research base & $\begin{array}{l}\text { Financial and statistical reports } \\
\text { characterizing } \\
\text { performance of the company } \\
\text { (balance sheet, income } \\
\text { statement) }\end{array}$ & $\begin{array}{l}\text { Specific reporting documents reflecting the } \\
\text { movement of the cash flow (cash flow } \\
\text { statement) }\end{array}$ \\
\hline 5 & $\begin{array}{l}\text { The result of the } \\
\text { study }\end{array}$ & $\begin{array}{l}\text { Assessment of the financial } \\
\text { condition of the entity }\end{array}$ & $\begin{array}{l}\text { Evaluation of the financial status and the } \\
\text { reasons underlying this situation and } \\
\text { leading to such a state of the entity. }\end{array}$ \\
\hline
\end{tabular}

* prepared by the author based on (Kovalev, 2008)

\section{AGGREGATED APPROACH TO UNDERSTANDING THE ESSENCE OF THE CASH FLOWS OF THE COMPANY}

The category "the cash flow of the company" is aggregated as it includes many types of the cash flows generated by the company and serving its economic activity. It should be noted that each company has its own "unique cash flow". It depends on the specifics of activity of each entity: from areas of operation, from the level of production, goods turnover, the number of employees, type of activity, tax policy, payment discipline and so on.
Within the aggregated approach Sorokina (2003, p. 45), generates the following definition: the cash flow is an aggregated category comprised of different types of flows serving the financial and economic activity of the company. This view is confirmed by Merna and Al-Thani in their work "Corporate risk management" (2008), who state that the cash flow can be determined by a company as a single flow as well as the aggregated number of flows for a fixed period of time.

According to Fabozzi \& Drake (2010, pp. 275276), "the cash flow is a flow of funds into the company during the time period". The main problem to determine the cash flows happens because the inflows and outflows of company's 
money can be distinguished, while at any time there is a reserve of cash but these reserve funds change in connection with: the size of the company, business demand for money and the management of working capital by the company.

According to the author of the thesis aggregated is the definition of the cash flow proposed by Podderiogin (2001) according to which the cash flow is a set of distributed in time events related to separate and logically complete fact of the change of an ownership of financial resources through the implementation of commitments between economic agents. A similar determination can be met in the works of Vasylchenko \& Pirog (2010, p. 45).

To further deepen the understanding of economic nature of "the cash flows" we give its basic characteristics which are distinguished by Professor I. O. Blank in his monograph which is devoted to research the cash flows of the company (Blank, 2002, p. 29). First of all, the cash flow is considered as the object of financial economic management of the company. This cash flow of the company is a process that: is directly related to the functioning of money and the monetary system of the country, with the formation, distribution and use of capital; reflects the shape and volume of the company functioning in the commodity and financial markets, use of various forms of credit; characterizes turnover and transformation of certain types of its assets; ensures the generation of economic benefit; is carried out taking into account the time factor, risk and liquidity.

\section{CONCLUSIONS}

Thus, having analyzed the diverse approaches to understanding the nature of the cash flows of the company it can be concluded that to formulate the definition of the cash flow its economic nature should be taken into account under which we can primarily understand the movement of cash. Some scholars add to the category of cash also "the cash equivalents" which is due to the specifics of the transformation of surplus cash in short-term investments that can be quickly converted into cash.
In our opinion, the aggregated approach to understanding the nature of the cash flows is the most appropriate, as it includes both dynamic and static (at a certain date) nature of this category. We define the cash flow of the company as the intended movement of cash which is expressed in their receipt, distribution, and disposal from operating, investing and financing activities. The result of the movement of cash is an available balance of cash and cash equivalents which serve as a static determinant of the cash flows.

To form a complete picture of the nature of the cash flows of the company all the key determinants that determine their economic nature must be taken into account. According to the content, it is a process that reflects the movement of the cash flows of the company. The cash flows mediate economic relations between the entities and act as a mechanism that ensures the movement of value between them.

According to its form, it is the total amount of all receipts and disposals that ensure uninterrupted cycling of the capital of the company in the process of simple or extended reproduction. According to the methodology of formation, it is a system of financial transactions that generate inflows and outflows of cash and aimed at solving specific, clearly defined tasks within the operating, investing and financing activities.

In order to clear the determination of certain structural components of the cash flow and to form a clear interpretation of these categories the inflow of cash funds will be called a positive (input, positive) cash flow and the outflow of cash funds will be called a negative (output, negative) cash flow, and the difference between positive and negative cash flows for each activity (in terms of operating, investing and financing activities) or for economic activity as a whole will be called a net cash flow.

So the cash flow of the company is a specific financial category that expresses the movement of cash and cash equivalents during the determined time period and ensures the implementation of economic relations arising in the process of realization of its operating, investing and financing activities. 


\section{WORKS CITED}

Blank, I. A. (2002). Cash Flow Management. Kiev: Nika-Center.

Brigham, J. (2009). Financial management (10th ed.). St. Petersburg: Peter.

Derzhavna Komisiya Ukrayiny po zapasakh korysnykh kopalyn pry Ministerstvi okhorony navkolyshn'oho pryrodnoho seredovyshcha Ukrayiny. (2005, Dec 07). Nakaz N 300. Retrieved from Zakon: http://zakon3.rada.gov.ua/laws/show/z0065-06

Fabozzi, F. J., \& Drake, P. P. (2010). The basics of finance: an introduction to financial markets, business finance, and portfolio management. New Jersey, USA: John Wiley \& Sons.

Fernandez, P. (2006). Cash flow is cash and is a fact: net income is just an opinion. IESE Business school-Universidad de Navarra. Retrieved from http://www.iese.edu/research/pdfs/DI-0629E.pdf

Investopedia. (2016). Cash flow. Retrieved from Investopedia: http://www.investopedia.com/terms/c/cashflow.asp

Kovalev, V. V. (2008). Financial management course. Moscow: Prospect.

Merna, T., \& Al-Thani, F. (2008). Corporate risk management. Padstow, Cornwall, UK: John Wiley \& Sons.

Nakaz № 290. (2006, Sep 06). Pro zatverdzhennya metodychnykh rekomendatsiy z rozroblennya biznes-planu pidpryyemstv. Retrieved from Ministerstvo Ekonomiky Ukrayiny: http://meold.kmu.gov.ua/minec/control/uk/publish/printable_article?art_id=147485

Podderiogin, A., Byriak, L., \& Kalach, N. (2001). Finansoviy menegemente. Kyiv, Ukraine: KNEY.

Pokrovskiy, N. Y. (2012). Improving methods of cash flow management in the chemical industry (thesis abstract)., (p. 24). Nizhniy Novgorod.

Sirotkin, S. A., \& Kilchevskaya, N. R. (2011). Financial management in the company (2nd ed.). Moscow: Unity-Dana

Sorokina, E. M. (2003). Analysis of the cash flows of the company: the theory and practice in the conditions of reforming of the Russian economy. Moscow: Finance and Statistics.

Tennet, J. (2014). Cash Flow Management: how not to be grounded. Moscow: Alpina Publisher.

Vasylchenko, Z. M., \& Pirog, D. V. (2010). Teoretychni osnovy upravlinnya hroshovimi potok ami banku. Visnik(1), 44-48.

Xaxonova, N. N. (2014). Features of the organization of effective companies' cash flow management providing communications services. Science \& World(1). Retrieved from http://www.wscience.com/2014-1-334.html

Received for publication: $\quad$ 24.03.2016

Revision received: $\quad 26.08 .2016$

Accepted for publication: $\quad 12.12 .2016$

\section{How to cite this article?}

Style - APA Sixth Edition:

Drebit, G. (2017, Jan 15). Theoretical approaches to understanding the nature of the cash flows of companies. (Z. Cekerevac, Ed.) MEST Journal, 5(1), 22-31. doi:10.12709/mest.05.05.01.03

Style - Chicago Sixteenth Edition:

Drebit, Galyna. "Theoretical approaches to understanding the nature of the cash flows of companies." Edited by Zoran Cekerevac. MEST Journal (MESTE) 5, no. 1 (Jan 2017): 22-31. doi:10.12709/mest.05.05.01.03 
Style - GOST Name Sort:

Drebit Galyna Theoretical approaches to understanding the nature of the cash flows of companies [Journal] // MEST Journal / ed. Cekerevac Zoran. - Belgrade - Toronto : MESTE, Jan 15, 2017. - 1 : Vol. 5. - pp. 22-31.

Style - Harvard Anglia:

Drebit, G., 2017. Theoretical approaches to understanding the nature of the cash flows of companies. MEST Journal, 15 Jan, 5(1), pp. 22-31.

Style - ISO 690 Numerical Reference:

Theoretical approaches to understanding the nature of the cash flows of companies. Drebit, Galyna. [ed.] Zoran Cekerevac. 1, Belgrade - Toronto : MESTE, Jan 15, 2017, MEST Journal, Vol. 5, pp. 22-31. 